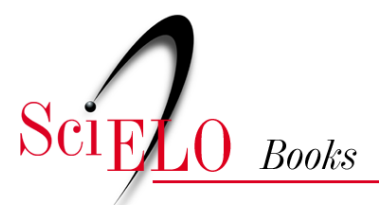

\title{
15. O que Montaigne Pensava dos Médicos e da Medicina de sua Época
}

\author{
Joffre Marcondes de Rezende
}

\section{SciELO Books / SciELO Livros / SciELO Libros}

REZENDE, J. M. O que Montaigne Pensava dos Médicos e da Medicina de sua Época. In: À sombra do plátano: crônicas de história da medicina [online]. São Paulo: Editora Unifesp, 2009, pp. 151-156. História da Medicina series, vol. 2. ISBN 978-85-61673-63-5. https://doi.org/10.7476/9788561673635.0016.

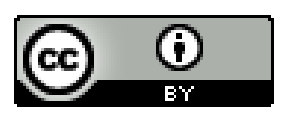

All the contents of this work, except where otherwise noted, is licensed under a Creative Commons Attribution 4.0 International license.

Todo o conteúdo deste trabalho, exceto quando houver ressalva, é publicado sob a licença Creative Commons Atribição 4.0.

Todo el contenido de esta obra, excepto donde se indique lo contrario, está bajo licencia de la licencia Creative Commons Reconocimento 4.0. 


\section{O que Montaigne Pensava dos Médicos e da Medicina de sua Época*}

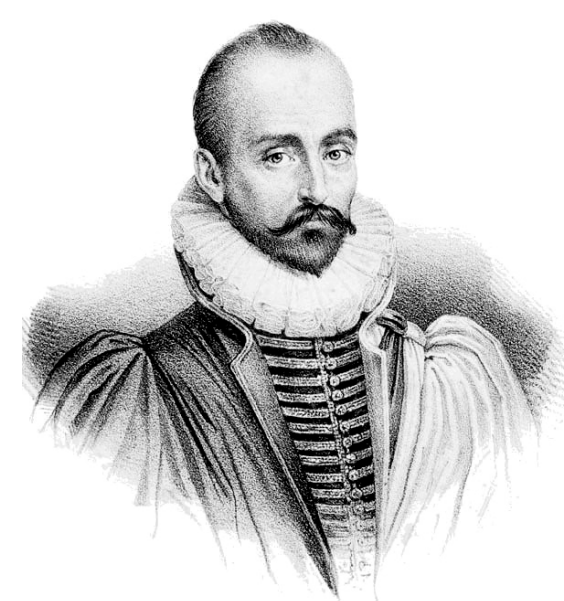

Michel de Montaigne, I553-I592.

W ichel Eyquem de Montaigne, humanista e filósofo francês, viveu de anos de idade seus conhecimentos de latim já causavam admiração. Estudou direito, foi magistrado, membro do Parlamento e prefeito de Bordéus por duas vezes. Casou-se aos 32 anos com Françoise de la Chassaigne. O casal teve seis filhas, das quais somente uma, Leonor, sobreviveu.

Aos 35 anos, com a morte de seu pai, herdou as terras e o castelo de Montaigne, em Dordogne, na França. Desfrutando de boa situação financeira, retirou-se para a sua propriedade em I 57 I, quando começou a escrever a obra que se tornou clássica, intitulada Ensaios, fruto de meditação, reflexão e observações pessoais. Em seus escritos, Montaigne demonstra uma sólida cultura humanística haurida nos clássicos latinos, como se observa na riqueza de citações de autores como Horácio, Ovídio, Sêneca, Lucrécio, Plutarco, Cícero, Juvenal e muitos outros.

* Modificado da revista Ser Médico, ıo, pp. 32-35, 2007. 
Os Ensaios constam de três livros e um total de 107 capítulos, nos quais são abordados os mais variados temas relacionados com a existência humana, tais como hábitos e costumes, sentimentos e paixões, organização social, doutrina moral e religiosa, filosofia, saúde e doença. A primeira edição foi publicada em I 580 ; a segunda, ampliada, em I 588 , e a terceira, póstuma, em 1593 (Doulant, s.d.).

Montaigne foi o criador desse gênero literário. Os temas que aborda não têm um encadeamento lógico nem um plano preestabelecido e podem ser lidos separadamente. Em todos eles encontramos reflexões e pensamentos filosóficos. Sua filosofia não é abstrata como de outros pensadores, mas voltada para os fatos comuns da vida cotidiana, tendo o homem como centro de suas preocupações e sua pessoa como exemplo das vicissitudes e contradições humanas. Os Ensaios, são, de certo modo, autobiográficos.

Os analistas de sua obra classificam sua filosofia como um misto de ceticismo e estoicismo: descrê da possibilidade de se atingir o conhecimento pleno através da razão e conforma-se com a precária condição humana, "de todas as criaturas a mais frágil e miserável, mas ao mesmo tempo... a mais orgulhosa”.

O envelhecimento e a morte são temas de profundas reflexões. No capítulo xx do Livro I lembra-nos a transitoriedade da vida e a certeza da morte. Citando Cícero, diz que "filosofar não é outra coisa senão preparar-se para a morte" e que, com sabedoria e inteligência "aprendemos a não ter receio da morte". E, mais adiante: "Partem todos como se acabassem de chegar [...]". "As flutuações a que se sujeita a nossa saúde, o enfraquecimento gradual que sofremos são meios que a natureza emprega para dissimular-nos a aproximação do fim." Considera, como Platão, a alma e o corpo inseparáveis. "Nossa compreensão, nosso julgamento e as faculdades de nossa alma sofrem de conformidade com o corpo e suas alterações. Não temos o espírito mais atilado, a memória mais viva, o raciocínio mais rápido quando a saúde é boa?”, indaga.

Ao mesmo tempo em que valoriza a saúde e acredita, como Hipócrates, no poder curativo da natureza, despreza a medicina como meio de preservá-la ou de recuperá-la na doença. Seus conceitos sobre os médicos e a medicina são ferinos e irônicos, como veremos nas seguintes passagens dos Ensaios, segundo a tradução, do francês para o português, de Sérgio Milliet (Montaigne, I972): 
Acerca da medicina, penso todo o bem e todo o mal que dizem, pois graças a Deus raramente apelo para ela. Trato-a ao contrário dos outros; não me preocupo nunca com ela e quando adoeço, em vez de confiar-me a ela, ponho-me a hostilizá-la, e a tempo. Aos que comigo insistem para que recorra às suas drogas, respondo que esperem até eu recobrar minhas forças e restabelecer-me a fim de melhor suportar seus efeitos (Livro I, capítulo 24, p. 70).

Quanta gente fica doente unicamente por efeito da imaginação. É frequente vermos quem se faça sangrar, purgar e medicar para curar males que só existem porque os imagina ter. Quando nos faltam males verdadeiros, a ciência no-los fornece. O que digo dos efeitos nefastos da medicina, aplica-se igualmente a qualquer outra ciência (Livro II, capítulo I2, p. 23 I).

Não é menos temerária a ciência com suas conjecturas. Escolhamos um ou dois exemplos apenas, senão nos perderíamos nesse oceano tão vasto e turvo dos erros cometidos pelos médicos (Livro II, capítulo I 2, p. 26I).

Há quanto tempo existe a medicina? Afirma-se, entretanto, que um inovador chamado Paracelso modifica e destroi as regras antigas e sustenta que até hoje só serviram para matar. Creio que provará facilmente esta afirmação, mas confiar-lhe a minha vida para que ateste a superioridade de seus métodos seria grande estupidez (Livro II, capítulo I2, p. 268).

Afirmam (os médicos) que nada sendo estável em nós, cumpre enfraquecer artificialmente a saúde. [...] É por isso que prescrevem purgantes e sangrias aos atletas. [...] Mais errados andavam ainda os que autorizavam fossem todos os criminosos condenados à morte, dissecados em vida pelos médicos a fim de que estes pudessem aprender no ser vivo o funcionamento de nossos órgãos internos e assim alcançar maior segurança na prática de sua arte (Livro II, capítulo 22, p. 3I7).

A minha antipatia pela arte (médica) é hereditária. Meu pai viveu 74 anos, meu avô 69, meu bisavô quase oitenta, todos sem que nunca tomassem qualquer medicamento. Meu tio paterno, tendo sido atacado de violenta e ininterrupta febre, resolveram os médicos declarar-lhe que se não confiasse nos cuidados deles estaria 
infalivelmente perdido (chamam de cuidados ao que em geral impede a cura). $\mathrm{O}$ bom homem, amedrontado com tão ameaçadoras palavras, respondeu-lhes: pois então sou um homem morto; mas Deus não tardou em desmentir o sombrio prognóstico. [...] Meus antepassados, por tendência inata e não raciocinada, apreciavam mediocremente a medicina; a simples vista de drogas era odiosa a meus pais. Desculpem-me os médicos a minha liberdade de linguagem.

[...] Antes de tudo, ensinou-me a experiência a temer os médicos, pois não há quem adoeça mais depressa e mais lentamente se cure do que os que se entregam nas mãos dos médicos. Até a saúde se altera com as dietas que eles inventam. Não se contentam os médicos com tratar das doenças, vigiam igualmente a saúde, a fim de que em nenhum momento lhes escape a vítima. [...] A presença do médico ou boticário atormenta a muitos, mais do que a própria enfermidade. Aliás, serão os médicos, eles mesmos, com sua saúde e média de vida, exemplos comprobatórios da eficácia de sua ciência? [...] E, em verdade, para que servem todas essas receitas confusas, senão para esvaziar o ventre? [...] Ademais, não acredito na utilidade de tal prática.

[...] Perguntaram a um lacedemônio como vivera tanto tempo com saúde: “porque não conheço drogas”, respondeu. O imperador Adriano, ao morrer, repetia sem cessar que o excesso de médicos o matara. Um mau lutador fizera-se médico: "coragem”, disse-lhe Diógenes, "tens razão; vais agora poder derrubar todos os que te derrubaram outrora". Como observa Nicocles, "têm eles a sorte de o sol iluminar-lhes os êxitos e a terra esconder-lhes os erros”.

Ademais, são peritos na arte de tirar partido dos acontecimentos, quaisquer que sejam. Se, por acaso, a natureza (ou qualquer outra causa) atua favoravelmente, atribuem a cura à sua ciência; cabe-lhes o mérito de todas as melhoras observadas, e vangloriam-se, em suma, junto aos que os solicitam, daquilo que nos curou, a mim e a mil outros, sem sua ajuda. [...] Ou, quando lhes convém melhor, utilizam a agravação em prol de seus interesses, procedendo da maneira seguinte que não falha: quando a doença piora em consequência do remédio afirmam que, sem este, fora bem mais grave; se o medicamento provoca ligeira febre em quem se achava resfriado, dizem que sem ele a febre seria mais violenta. Pouco lhes importa o êxito, pois o prejuízo também lhes acarreta lucros.

Esopo, autor de talento excepcional [...] conta-nos de um paciente que responde às perguntas de seu médico acerca do efeito dos remédios recomendados; “Transpirei muito". "Excelente.” Mais tarde, não tendo visto a vítima durante 
algum tempo indaga como passara desde o primeiro dia: "Senti muito frio, e violentos tremores". "Muito bom.” Uma terceira vez, inquirindo ainda do estado do mesmo doente, ouve a seguinte resposta: "Sinto-me inchar, como se estivesse com hidropisia". "Perfeito." E quando o criado do enfermo chega, após essa última visita, para saber da saúde do amo, este lhe diz: "Vou bem, meu amigo, tão bem em verdade, que acho que estou morrendo". [...] Se Esculápio, o mestre de todos eles, foi fulminado por ter reanimado Hipólito, por que seus continuadores, que matam tanta gente, deveriam gozar de imunidades?

[...] Certo médico jactava-se perante Nicocles da autoridade considerável que sua arte havia alcançado: "Sem dúvida”, observou Nicocles, "podes matar impunemente”. [...] Quem jamais viu um médico confirmar simplesmente a receita de um confrade, sem nada acrescentar ou cortar? Revelam assim a inanidade de sua arte e mostram que mais os preocupam a própria fama e os lucros do que os doentes. [...] Quando se reúnem vários médicos em torno de um mesmo caso, desmoralizam a profissão com dissensões e brigas.

[...] Quantos médicos não vemos, atribuindo-se uns aos outros a culpa pela morte de suas vítimas? [...] E se o erro de um médico é perigoso, eis-nos em bem má situação, pois é muito difícil que não o repita amiúde. [...] Cada vez que os consultei, por ínfima que fosse a dificuldade, nunca encontrei três da mesma opinião (Livro II, capítulo 37, pp. 35 I-355).

Não os ataco e sim a sua arte; não os recrimino por tirarem proveito de nossa tolice, porque todos agem de igual maneira e não faltam profissões mais ou menos honrosas que só subsistem e prosperam abusando do público. [...] O medo da dor e da morte, o desejo exacerbado de cura é que nos cegam. É simplesmente a covardia que torna tão complacente a nossa fé (Livro II, capítulo 37, p. $35^{8}$ ).

Descrevem os médicos nossos males como um pregoeiro de aldeia descreve o cavalo e cão perdidos, dizendo a cor do pelo, o tamanho e a raça, mas incapazes de reconhecê-lo se lho apresentam (Livro III, capítulo I3, p. 488).

Montaigne sofria de calculose biliar. Faleceu aos 59 anos de idade, certamente sem recorrer aos médicos. 


\section{Referências Bibliográficas}

Doulant, T. Biographie de Michel Eyquem de Montaigne. Disponível em http://www. alalettre.com/montaigne-bio.htm, acesso em 23 ago. 2002.

Montaigne, M. Ensaios. Trad. Sérgio Milliet. São Paulo, Abril Cultural, I972. 